\title{
Pemodelan Site pada Heterogen Network 5G Menggunakan Optimized Network Enggineering Tools
}

\author{
Aisah $^{\# 1}$, Moechammad Sarosa ${ }^{\# 2}$, Kristina Widjayanti\# \\ \# Jurusan Teknik Elektro, Politeknik Negeri Malang \\ Jalan Soekarno Hatta No.9 Malang 65141Malang \\ 1aisahzahra@gmail.com \\ 2msarosa@polinema.ac.id \\ ${ }^{3}$ kristina@polinema.ac.id
}

\begin{abstract}
Abstrak- Penelitian ini melakukan analisis desain Pemodelan Site Pada Heterogen Network 5G (HetNet 5G) Menggunakan Optimized Network Enggineering Tools. Pemodelan menggunakan perhitungan dan simulasi untuk menganalisis traffic dan coverage generasi sebelumnya yaitu 4G LTE yang diterapkan pada jaringan seluler existing pada site HetNet 5G, untuk memenuhi kebutuhan penempatan site 5G. Hasil penelitian ini diharapkan dapat digunakan sebagai rekomendasi bagi operator seluler. Data yang digunakan simulasi diperoleh dari salah satu operator seluler Indonesia di wilayah Kecamatan Lowokwaru Malang yaitu sebanyak 40 site. Berdasarkan perhitungan dan simulasi dari ke 40 site tersebut diperoleh 6 site yang potensi diterapkan site teknologi 5G. Tahapan penelitian ini diawali dengan penentuan lokasi wilayah yang potensi diterapkan site $5 \mathrm{G}$, data lokasi koordinat dan parameter site untuk perhitungan prediksi kenaikan jumlah penduduk selama 5 tahun yang akan datang, analisis morfologi dan wilayah point of interes (POI), serta kapasitas penduduk sedangkan perhitungan troughput menjadi kriteria di masing-masing kelurahan. Selanjutnya, hasil perhitungan dan simulasi di plotkan pada Map Info untuk menampilkan persebaran site di masingmasing kelurahan. Site yang memenuhi potensi 5G di plot dengan diagram voronoi aplikasi dalam Map Info sesuai radius 4G dan 5G. Diagram voronoi menampilkan coverage berbeda teknologi $4 \mathrm{G}$ dan $5 \mathrm{G}$.
\end{abstract}

Kata kunci-4G, Site HetNet 5G, Voronoi, Atoll, Map Info.

\section{PEndahuluan}

Teknologi seluler berkembang dengan cepat yang mengarah teknologi seluler 5G, sebagai dampak dari komunikasi telah menjadi kebutuhan penting bagi masyarakat. Kebutuhan teknologi mendorong pengguna telepon seluler dalam berkomunikasi dan mengakses internet terus meningkat sehingga pengembangan dalam peningkatan kecepatan, kualitas jaringan dan luas jangkauan harus terus dilakukan. Teknologi 5G diharapkan dapat memberikan solusi dan melengkapi atas kekurangan yang dialami teknologi sebelumnya [1].
Penambahan jumlah dan lokasi menara sudah merupakan tuntutan yang wajib dipenuhi oleh penyelenggara telekomunikasi. Namun di sisi lain, penempatan menara terlalu banyak tanpa perencanaan yang tepat akan menganggu pemandangan di wilayah tersebut. Sehingga perlu adanya koordinasi pembangunan menara antara operator dan Pemerintah Daerah. Langkah tersebut merupakan solusi dari dua permasalahan yaitu penambahan menara baru untuk memperluas daerah cakupan pada wilayah baru maupun untuk mengatasi blank spot dan penerapan cell splitting dan pembentukan sel-sel mikro pada wilayah yang memiliki kepadatan pelanggan yang tinggi dan terus meningkat untuk meningkatkan kapasitas layanan [2]

Untuk menyelesaikan permasalahan tersebut dibutuhkan suatu software aplikasi untuk menyusun master plan yang lengkap dan rinci tentang penataan menara menggunakan software Map Info dan Atoll. Potensi kebutuhan jaringan 5G di kecamatan Lowokwaru Kota Malang menggunakan forecasting (peramalan) untuk memprediksi jumlah pengguna yang terus bertambah dalam 5 tahun mendatang [2]

Penelitian yang dilakukan [3] dan [4] pada tahun 2019 menganalisis potensi kebutuhan jaringan LTE di Kota Malang menggunakan forecasting (peramalan) untuk memprediksi jumlah pengguna LTE terus bertambah dalam 5 tahun mendatang. Hasil prediksi jumlah pengguna LTE untuk mencari potensi kebutuhan eNobeB pada jaringan seluler existing.

\section{LANDASAN TEORI}

\section{A. Perkembangan Teknologi 5G}

Berbagai pelaku industri Telekomunikasi di dunia telah memulai sejumlah persiapan untuk menyongsong era 5G. Analisis terhadap kesiapan teknologi dan infrastruktur, serta regulasi untuk mempersiapkan masuknya era generasi 5G. Teknologi 5G menawarkan berbagai keunggulan dari teknologi sebelumnya [5]. 


\section{B. Kondisi Alam atau Tipe Daerah}

Daerah yang memiliki perbukitan berbeda dengan daerah yang berada di perkotaan banyak gedung-gedung tinggi. Berdasarkan keberadaan penghalang dan tingkat kepadatan (obstacle) dapat mengganggu proses pentrasmisian yang berlangsung [6]:

1) Daerah Urban: Kategori daerah wilayah yang dipadati penduduk dengan bangunan-bangunan besar dan memiliki gedung-gedung yang rapat serta tinggi dengan jumlah banyak. Penghalang sinyal antara MS dan BTS tingginya lebih dari 20 meter. Kepadatan penduduk $\geqslant$ 7348 jiwa $/ \mathrm{km}^{2}$.

2) Daerah Sub Urban: Peralihan morfologi urban dan rural dengan jumlah penduduk yang tidak terlalu padat, ditandai dengan pemukiman penduduk yang berderet, sebelah-menyebelah atau gabungan, terdapat pohon tinggi atau penghalang dengan tinggi antara 12-20 m. Kepadatan penduduk $\leqslant 7347 \mathrm{jiwa} / \mathrm{km}^{2}$ hingga $\geqslant$ $1949 \mathrm{jiwa} / \mathrm{km}^{2}$.

3) Daerah Rural: adalah kategori jenis wilayah yang memiliki jumlah bangunan sedikit dan jarang atau dapat berupa alam terbuka. Kepadatan penduduk $\leqslant 1948$, misalnya daerah pedesaan [7].

\section{Point of Interest (POI)}

POI merupakan sebuah titik spesifik dari suatu lokasi dimana seseorang dapat menemukan suatu manfaat atau suatu hal yang menarik di dalamnya. POI dapat dideteksi melalui smartphone dan software Google Maps [8].

\section{Heterogen network $5 G$}

Heterogen Network adalah topologi jaringan dengan teknologi sel yang menggambarkan banyak tingkatan jaringan komunikasi seluler [9]. Jenis-jenis cell [10]:

1) Macro Cell: merupakan jenis sel yang biasa digunakan pada daerah suburban atau daerah pingggiran kota karena coverage area macro cell sangat luas. Radius macro cell umumnya lebih dari $3 \mathrm{~km}$ dan terletak di area outdoor.

2) Micro Cell: merupakan jenis sel yang biasa digunakan pada daerah urban atau daerah perkotaan yang memiliki kepadatan penduduk yang tinggi. Radius pada micro cell antara $0,2 \mathrm{~km}$ sampai $2 \mathrm{~km}$ dan terletak pada area indoor maupun outdoor.

3) Pico cell: merupakan jenis sel yang biasa digunakan di dalam suatu gedung atau ruangan yang bersifat indoor. Radius pada pico cell antara $0,1 \mathrm{~km}-0,2$ $\mathrm{km}$.

Geografis Kota Malang secara astronomis berdasarkan data Badan Pusat Statistik memiliki wilayah seluas 110,02 $\mathrm{km}^{2}$ yang terbagi menjadi 5 kecamatan. Sedangkan
Kecamatan Lowokwaru memiliki luas wilayah $22,60 \mathrm{~km}^{2}$ yaitu 20,53\% terhadap luas Kota Malang [11].

\section{E. Planning Jaringan}

Perencanaan untuk menentukan jumlah site yang akan dibangun pada suatu daerah atau wilayah untuk menyediakan suatu layanan seluler.

1) Capacity Planning: merupakan teknik perencanaan jaringan untuk mengetahui jumlah site dengan mempertimbangkan kebutuhan trafik pelanggan di suatu wilayah. Tujuan capacity planning adalah untuk menghitung atau mengestimasi jumlah base station yang dibutuhkan agar dapat meminimalisasikan terjadinya kemacetan lalu lintas komunikasi berdasarkan jenis layanan, penetrasi layanan, dan lama pengguna layanan efektif dan busy hour call attempt (BHCA) [12].

2) Klasifikasi Jenis Layanan: pada jaringan seluler klasifikasi untuk bit rate user tiap jenis layanan pada jaringan untuk uplink dan downlink pada Tabel 1[13].

TABEL I

BIT RATE USER TIAP LAYANAN [13]

\begin{tabular}{|c|c|c|}
\hline Jenis Layanan & $\begin{array}{c}\text { DL bit rate } \\
\text { (Kbps) }\end{array}$ & $\begin{array}{c}\text { UL bit rate } \\
\text { (Kbps) }\end{array}$ \\
\hline Speech / Voice & 16 & 16 \\
\hline Simple Message & 14 & 14 \\
\hline Switched Data & 64 & 64 \\
\hline Medium Multimedia & 384 & 384 \\
\hline High Multimedia & 2000 & 2000 \\
\hline $\begin{array}{c}\text { High Interactive } \\
\text { Multimedia }\end{array}$ & 128 & 128 \\
\hline
\end{tabular}

3) Penetrasi Layanan: Penetrasi Layanan adalah estimasi yang digunakan untuk memprediksi pengguna pada setiap jenis layanan yang digunakan oleh pelanggan. Adapun penetrasi layanan seluler berdasarkan standar ITU pada Tabel 2 .

TABEL II

PENETRASI LAYANAN [13]

\begin{tabular}{|c|c|}
\hline Jenis Layanan & DL bit rate (Kbps) \\
\hline Speech / Voice & 73 \\
\hline Simple Message & 40 \\
\hline Switched Data & 13 \\
\hline Medium Multimedia & 15 \\
\hline High Multimedia & 15 \\
\hline High Interactive Multimedia & 25 \\
\hline
\end{tabular}

4) BHCA: merupakan penggunaan layanan selama jam sibuk merupakan rasio antara jumlah semua pengguna yang melakukan panggilan pada saat jam sibuk dengan jumlah keseluruhan pengguna suatu layanan pada daerah tersebut.

5) Forecasting Jumlah Pelanggan: bertujuan untuk mengetahui jumlah pelanggan yang akan menggunakan layanan dari jaringan yang akan dibangun. Sebelumnya 
harus diketahui presentase tingkat pertumbuhan penduduk, menggunakan rumus [14].

$\mathrm{x} \%=(($ tahun terakhir-tahun awal $) /($ tahun awal $)) \times 100$

Selanjutnya menghitung jumlah penduduk tahun berikutnya menggunakan rumus sebagai berikut [12].

$$
\mathrm{Pt}=\mathrm{P} 0(1+\mathrm{x} \%) \mathrm{t}
$$

Hasil perhitungan akan digunakan untuk mencari estimasi pelanggan seluler menggunakan total teledensitas, yaitu perbandingan antara jumlah pengguna telepon seluler dengan jumlah penduduknya, menggunakan rumus sebagai berikut [12].

$$
\mathrm{P}=\mathrm{x} \% \times \mathrm{Pt}
$$

Dengan menggunakan teledensitas sehingga dapat mengetahui data pengguna seluler setiap Kelurahan di Kecamatan Lowokwaru kota Malang. Teledensitas jumlah pengguna seluler dapat dihitung dengan mengansumsikan teledensitas jumlah pengguna seluler di Pulau Jawa yaitu sebesar $86,60 \%$ [15].

6) Traffic Capacity 5G: Dalam perhitungan kapasitas trafik pada jaringan $5 \mathrm{G}$ menggunakan formula offered data volume (ODV). Frekuensi yang dipakai yaitu $28 \mathrm{GHz}$ dengan bandwidth $100 \mathrm{MHz}$ dan luas cakupan jaringan 5G yaitu 200 meter. Perhitungan dilakukan pada saat jam sibuk dengan tujuan untuk mendapatkan kapasitas maksimum jaringan, menggunakan formula ODV sebagai berikut [13]:

$\mathrm{ODV}=\mathrm{BHCA} \times$ Service Penetration $\times$ Potensial User/Km2 $\times$ Service Throughput [Kbps] $\times$ Effective Call Duration [sec].

Kepadatan jumlah penduduk per $\mathrm{km}$ menggunakan perhitungan sebagai berikut [13].

$$
\text { Kepadatan User } / \mathrm{Km}^{2}=\Sigma \text { user/(Luas Wilayah) }
$$

7) Kapasitas Sistem: Perhitungan dalam menentukan kapasitas pada sistem seluler menggunakan rumus sebagai berikut [16]:

Strategi penambahan kapasitas sel kecil = $\alpha \times \mathrm{y} \times \mathrm{BW}$

8) Perhitungan Jumlah Site: untuk mengetahui banyak $B S$ per site yang dibutuhkan pada suatu daerah. Berdasarkan perhitungan total ODV dan kapasitas sistem maka perhitungan jumlah site menggunakan rumus sebagai berikut [17]. Luas Cell Coverage (L), Jumlah Cell, dan Radius.
9) MapInfo: merupakan suatu perangkat lunak yang mendukung sistem telekomunikasi dalam hal pemetaan. Perangkat ini memiliki kemampuan menggabungkan dan menampilkan atau pengimplementasikan Sistem Informasi Geografik (SIG) [18]. [19]. Kegunaan Mapinfo dalam telekomunikasi antara lain. Mapping peta jalan, kontur, vektor dan lain-lain yang berhubungan dengan pemetaan. Mapping posisi BTS, Transmisi, BSC, MSC dan lain-lain. Mempermudah dalam pengecekan neigborlist cell untuk mempermudah dalam hal penzonaan menara telekomunikasi.

10) Atoll : merupakan software yang digunakan oleh radio network planner (RNP) engineer untuk melakukan pengawasan coverage prediction. Software ini juga terintegrasi dengan beberapa kemampuan untuk mendesain jaringan RAT untuk 3GPP (GSM/UMTS/LTE) dan 3GPP2 (CDMA/LTE). Atoll support Atoll support teknologi sebagai GSM/GPRS/EDGE, UMTS/HSPA, CDMA 2000 1X RTT/EV-DO, LTE, TD-SCDMA, WiMAX 802.16d, WiMAX 802.16e, dalam bagian Project Templates tersebut terdapat pilihan mengenai jenis projek yang akan dibuat [1] [18].

11) Diagram Voronoi : adalah metode untuk membagi wilayah atau ruang diantara sekumpulan titiktitik yang menetapkan area untuk masing-masing. Properti utama dari wilayah adalah bahwa setiap area mewakili ruang dimana titik-titik tersebut adalah tetangga terdekat (nearest neighbor). Diagram voronoi menunjukan pembagian suatu wilayah tertentu menjadi beberapa bagian yang disebut cell, dimana masing-masing bagian berisi satu titik lokasi yang disebut site. Dengan demikian, setiap titik pada wilayah tersebut telah dipasaangkan dengan site yang terdekat [20], [21],

\section{METODE PENELITIAN}

Penelitian ini bertujuan untuk menganalisa kebutuhan site 5G pada wilayah Kecamatan Lowokwaru, Kota Malang. Penelitian ini menggunakan metode forecasting (peramalan) dan perhitungan pada coverage area serta menggunakan aplikasi Map Info dan Atoll untuk melakukan simulasi. Data simulasi diperoleh dari salah satu operator Telekomunikasi Indonesia di wilayah Kecamatan Lowokwaru Malang.

Metode yang digunakan untuk penelitian meliputi, studi literatur yang berhubungan dengan pemodelan traffic dan coverage, pengumpulan data, simulasi, perhitungan dan analisis hasil simulasi, analisis hasil pemodelan, dan kesimpulan. Data yang dibutuhkan dalam penelitian meliputi parameter data koordinat site, parameter transmitter, peta wilayah dapat menggunakan peta digital dan google map. Data site yang digunakan untuk simulasi adalah cell name, longitude, latitude, address [22] address site sebanyak 40 site [13].

Kriteria Morfologi berdasarkan wilayah Urban dengan kepadatan penduduk $\geqslant 7348$ jiwa/km2, wilayah Sub Urban dengan kepadatan penduduk $\leqslant 7347$ jiwa/km2 
hingga $\geqslant 1949 \mathrm{jiwa} / \mathrm{km} 2$, wilayah rural dengam kepadatan penduduk $\leqslant 1948$.

Kriteria Point of Interest (POI), setelah klasifikasi berdasarkan kriteria morfologi, pengambilan POI berdasarkan tempat yang dikunjungi banyak orang, seperti universitas, rumah sakit, mall, pasar, tempat rekreasi dan pinggir jalan raya ramai. Untuk memperoleh kriteria site berdasarkan POI menggunakan Google Maps dan kriteria morfologi. Hasil simulasi Voronoi ditampilkan menggunakan Map Info.

\section{HASIL DAN PEMBAHASAN}

\section{A. Kebutuhan Data}

Data yang dibutuhkan untuk analisis penelitian meliputi data koordinat site eNodeB (4G), antena sektoral, azimut, nama site, alamat site, peta digital, Google maps, Map Info, software Atoll, sofware Voronoi, data jumlah penduduk kecamatan Lowokwaru dari BPS, jumlah site eNodeB dari operator wilayah kecamatan Malang berjumlah 40 site. Hasil perhitungan pertumbuhan penduduk tahun 2016-2020, usia produktif (usia 15-54 tahun) Kota Malang sebesar 567.148.

Penduduk usia produktif setiap kelurahan kecamatan Lowokwaru terdapat 12 kelurahan, selama 5 tahun 20162020, dengan pengali sebesar 0,49\% diperoleh 129.245 penduduk untuk memprediksi jumlah pelanggan pengguna jaringan seluler.

Estimasi pertumbuhan jumlah penduduk 5 tahun mendatang dari 12 kelurahan di kecamatan Lowokwaru tahun 2021-2025 ditampilkan pada Gambar 1.

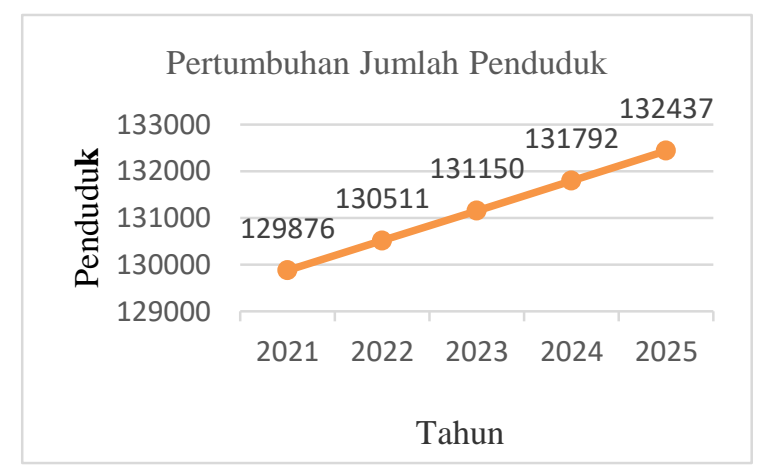

Gambar. 1 Grafik pertumbuhan jumlah penduduk tahun 2021-2025 kecamatan Lowokwaru 12 kelurahan

Hasil dari perhitungan Gambar 1 digunakan untuk mencari estimasi pelanggan seluler tanpa teledensitas dan diperoleh 132.437 pelanggan.

Hasil dari perhitungan Gambar 2 digunakan untuk mencari estimasi pelanggan seluler dengan mengasumsikan teledensitas jumlah pengguna seluler di Pulau Jawa yaitu sebesar 86,60\% [15]. Dengan hasil tahun 2025 dan diperoleh 114.684 pelanggan seluler.

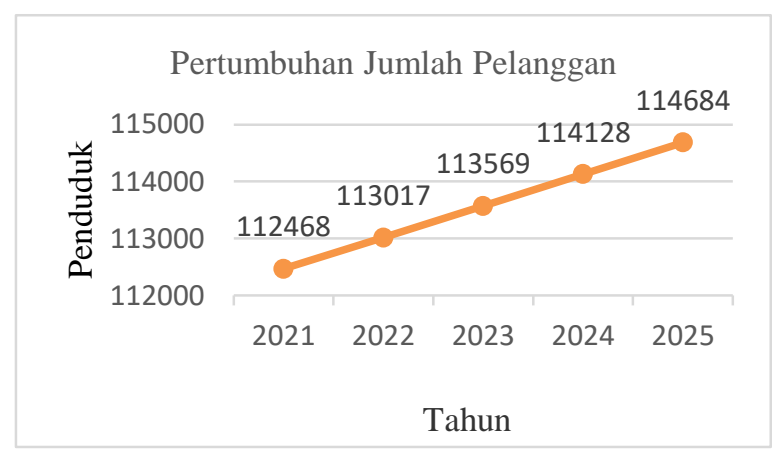

Gambar 2 Grafik pertumbuhan jumlah penduduk tahun 2021-2025 kecamatan Lowokwaru 12 kelurahan

\section{B. Hasil Klasifikasi Berdasarkan Morfologi}

Salah satu aspek yang digunakan untuk mengklasifikasi wilayah kecamatan Lowokwaru adalah dengan jumlah kepadatan penduduk (morfologi).

Hasil perhitungan kepadatan tiap kelurahan dan jenis klasifikasi berdasarkan morfologi. Tedapat 3 kelurahan pada wilayah urban, yaitu kelurahan Dinoyo, Sumbersari dan Lowokwaru, 8 kelurahan pada wilayah sub urban, yaitu kelurahan Merjosari, Ketawanggede, Jatimulyo, Tulusrejo, Mojolangu, Tunjungsekar, Tunggulwulung dan Tlogomas. Pada wilayah rural terdapat 1 kelurahan yaitu Tasikmadu. Pada penelitian ini mengambil wilayah urban karena jaringan 5G berpotensi pada daerah padat penduduk terutama perkotaan. Tabel 3 adalah hasil data site setelah klasifikasi morfologi.

TABEL III

DATA SITE BTS BERDASARKAN KLASIFIKASI MORFOLOGI

\begin{tabular}{|c|c|c|c|}
\hline No & Cell Name & $\begin{array}{l}\text { Address } \\
\text { Site }\end{array}$ & $\begin{array}{c}\text { Prediksi } 5 \\
\text { Tahun } \\
2025\end{array}$ \\
\hline 1 & $\begin{array}{l}\text { Mlg095mm1_Dinoy } \\
\text { omalang }\end{array}$ & Dinoyo & 10674 \\
\hline 2 & $\begin{array}{l}\text { Mlg039mm1_Uinm } \\
\text { alang }\end{array}$ & Dinoyo & 10674 \\
\hline 3 & $\begin{array}{l}\text { Mlg339mm1_Unis } \\
\text { mapab }\end{array}$ & Dinoyo & 10674 \\
\hline 4 & $\begin{array}{l}\text { Mlg615mm1_Mete } \\
\text { orcellmcme }\end{array}$ & Dinoyo & 10674 \\
\hline 5 & $\begin{array}{l}\text { Mlg940mm1_Maha } \\
\text { dputrauindmtmcp }\end{array}$ & Dinoyo & 10674 \\
\hline 6 & $\begin{array}{l}\text { Mlg963mm1_Pere } \\
\text { mpatansainsuindmt }\end{array}$ & Dinoyo & 10674 \\
\hline 7 & $\begin{array}{l}\text { Mlg025mm1_Mitra } \\
2\end{array}$ & $\begin{array}{c}\text { Lowokwa } \\
\text { ru }\end{array}$ & 9854 \\
\hline 8 & $\begin{array}{l}\text { Mlg290mm1_Sedap } \\
\text { malammcme }\end{array}$ & $\begin{array}{c}\text { Lowokwa } \\
\text { ru }\end{array}$ & 9854 \\
\hline 9 & $\begin{array}{l}\text { Mlg343mm1_Mang } \\
\text { garibs }\end{array}$ & $\begin{array}{c}\text { Lowokwa } \\
\text { ru }\end{array}$ & 9854 \\
\hline 10 & $\begin{array}{l}\text { Mlg103mm1_Pond } \\
\text { okharapanindah1 }\end{array}$ & $\begin{array}{c}\text { Sumbersar } \\
\text { i }\end{array}$ & 9850 \\
\hline 11 & $\begin{array}{l}\text { Mlg334mm1_Beng } \\
\text { uramcme }\end{array}$ & $\begin{array}{c}\text { Sumbersar } \\
\mathrm{i}\end{array}$ & 9850 \\
\hline
\end{tabular}




\section{Klasifikasi Berdasarkan Point of Interest (POI)}

.Klasifikasi berdasarkan POI terdapat 3 kelurahan, yaitu tempat yang dikunjungi banyak orang, seperti kampus, rumah sakit, dan pinggir jalan raya ramai, mall, sekolah, tempat wisata dan pasar. Letak Site dan POI pada google Maps, legenda di site warna hitam.

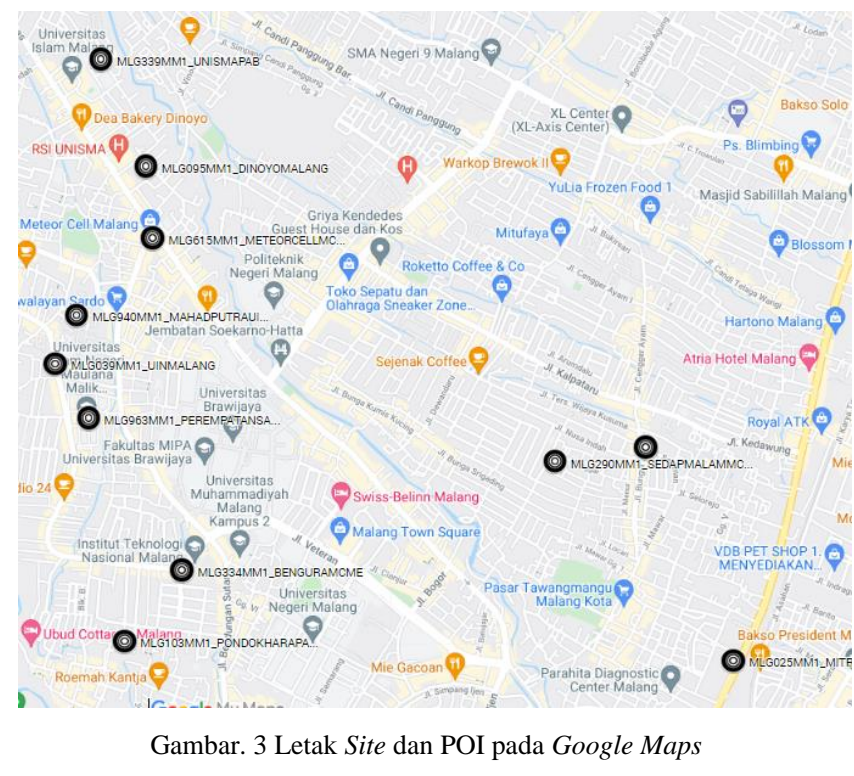

Data site yang potensi 5G, terdapat 6 site dalam Tabel 4, setelah klasifikasi berdasarkan POI.

TABEL IV

DATA SITE BTS BERDASARKAN KLASIFIKASI POI

\begin{tabular}{|c|c|c|c|c|}
\hline No & Cell Name & Address & $\begin{array}{c}\text { Address } \\
\text { Site }\end{array}$ & $\begin{array}{l}\text { Prediksi } \\
5 \text { Tahun } \\
\end{array}$ \\
\hline 1 & $\begin{array}{l}\text { Mlg095mm1_ } \\
\text { Dinoyomalan } \\
\text { g }\end{array}$ & $\begin{array}{l}\text { Jl.Mt } \\
\text { Haryono XIII }\end{array}$ & Dinoyo & 10674 \\
\hline 2 & $\begin{array}{l}\text { Mlg339mm1_ } \\
\text { Unismapab }\end{array}$ & $\begin{array}{ll}\text { Jl.Tata } & \text { Surya } \\
\text { I, } & \text { RT.07 } \\
\text { RW.06 }\end{array}$ & Dinoyo & 10674 \\
\hline 3 & $\begin{array}{l}\text { Mlg615mm1_ } \\
\text { Meteorcellmc } \\
\text { me }\end{array}$ & $\begin{array}{l}\text { J1. Gajayana } \\
519\end{array}$ & Dinoyo & 10674 \\
\hline 4 & $\begin{array}{l}\text { Mlg963mm1_ } \\
\text { Perempatansai } \\
\text { nsuindmt }\end{array}$ & $\begin{array}{l}\text { Jl. Sunan } \\
\text { Kalijaga }\end{array}$ & Dinoyo & 10674 \\
\hline 5 & $\begin{array}{l}\text { Mlg025mm1_ } \\
\text { Mitra2 }\end{array}$ & $\begin{array}{lr}\text { Jl. } & \text { Letjen } \\
\text { Sutoyo } & \text { No. } \\
27 & \text { C, } \\
\text { Primayasa } & \\
\end{array}$ & $\begin{array}{l}\text { Lowok } \\
\text { waru }\end{array}$ & 9854 \\
\hline 6 & $\begin{array}{l}\text { Mlg334mm1_- } \\
\text { Benguramcme }\end{array}$ & $\begin{array}{l}\text { Jl. } \\
\text { Bendungan } \\
\text { Sigura-Gura } \\
\text { No. 4, Kav. 3, } \\
\text { RT. 01, RW. } \\
07\end{array}$ & $\begin{array}{c}\text { Sumbers } \\
\text { ari }\end{array}$ & 9850 \\
\hline
\end{tabular}

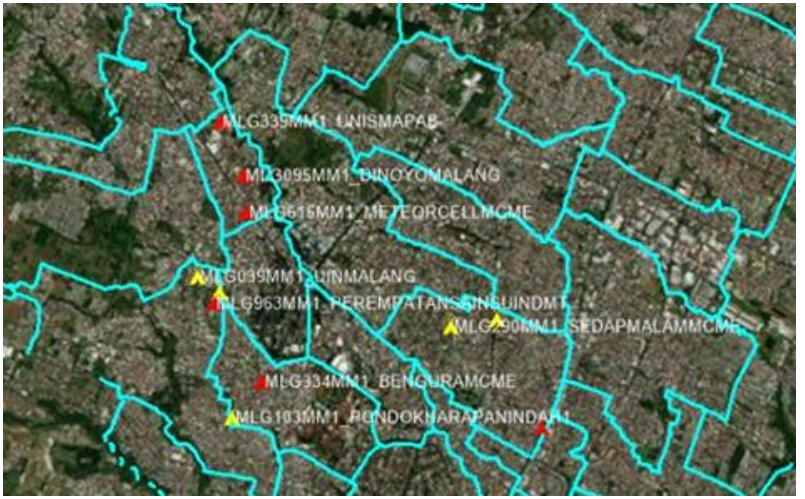

Gambar. 4 Plot Site berdasarkan klasifikasi POI dan LEGENDA

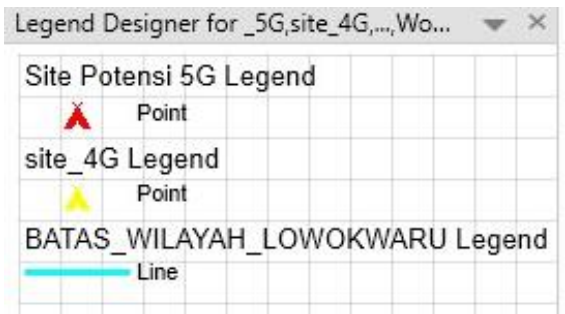

Gambar. 5 Legenda plot site klasifikasi POI dan legenda

Gambar 4 adalah plot 11 site berwarna kuning berdasarkan klasifikasi morfologi dan Gambar 5 adalah menjelaskan legenda untuk site warna kuning (4G) dan site berwarna merah $(5 \mathrm{G})$ untuk klasifikasi berdasarkan POI mendapatkan 6 site merupakan site yang berpotensi teknologi 5G.

Plot site di software Atoll yang berpotensi site 5G dan mengukur jarak antara point analisis (user) dan site BTS, sebagai perbandingan dan pengukuran radius teknologi 4G dan 5G (lihat Gambar 6). Teknologi 4G diukur radius diperoleh $0 \mathrm{~km}-2 \mathrm{~km}$, sedangkan teknologi $5 \mathrm{G}$ berdasarkan kalsifikasi POI.

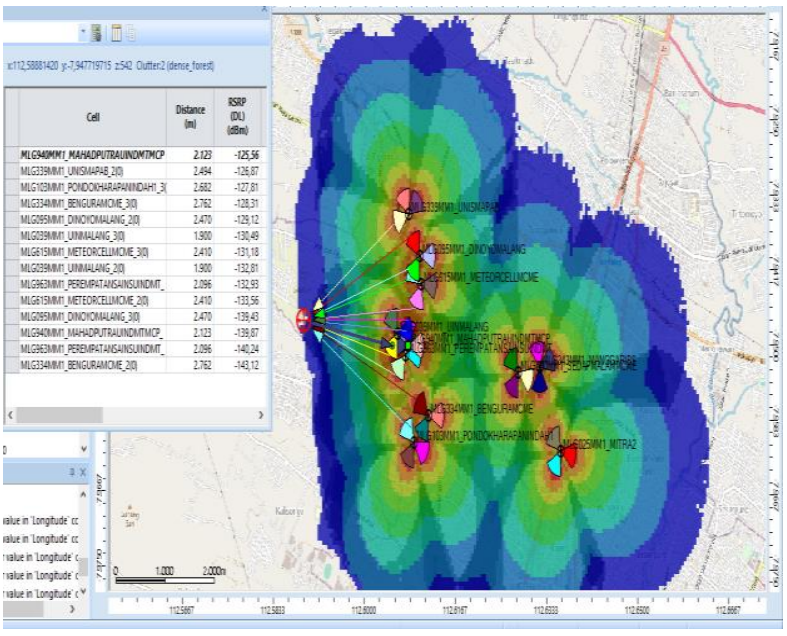

Gambar. 6 Plot site untuk mengukur radius taeknologi 4G dan 5G 


\section{Traffic Capacity 5G}

Dalam perhitungan kapasitas trafik pada jaringan 5G menggunakan formula offered data volume (ODV). Perhitungan dilakukan pada saat jam sibuk dengan tujuan untuk mendapatkan kapasitas maksimum jaringan. Kepadatan pelanggan diambil dari 3 kelurahan untuk 6 site yang masuk dalam kategori wilayah Urban, yaitu Kelurahan Dinoyo, Lowokwaru dan Sumbersari [7], [22].

TABEL V

HASIL KEPADATAN PELANGGAN DARI 3 KELURAHAN

\begin{tabular}{|c|c|c|c|}
\hline Keterangan & $\begin{array}{c}\text { Kel. } \\
\text { Dinoyo } \\
\text { (4 site) }\end{array}$ & $\begin{array}{c}\text { Kel. } \\
\text { Lowokwaru } \\
\text { (1 site) }\end{array}$ & $\begin{array}{c}\text { Kel. } \\
\text { Sumbersari } \\
\text { (1 site) }\end{array}$ \\
\hline $\begin{array}{c}\text { Jumlah Pelanggan } \\
\text { (user) }\end{array}$ & 10674 & 9854 & 9850 \\
\hline $\begin{array}{c}\text { Luas Wilayah } \\
\left(\mathrm{km}^{2}\right)\end{array}$ & 1,17 & 1,23 & 1,28 \\
\hline $\begin{array}{c}\text { Kepadatan } \\
\text { User/Km }\end{array}$ & 9123 & 8011 & 7695 \\
\hline
\end{tabular}

Hasil Perhitungan ODV Kelurahan Dinoyo, Lowokwaru, dan Sumbersari, adalah :

ODV $=$ BHCA $\times$ Service Penetration $\times$ Potensial User $/ \mathrm{km}^{2} \times$ Service Throughput $[\mathrm{Kbps}] \times$ Effective1

1. Hasil Kelurahan Dinoyo $=\sum \mathrm{ODV}=3795171,649$ $\mathrm{kbit} / \mathrm{hour} / \mathrm{km}^{2}=1025,02 \mathrm{Kbps} / \mathrm{km}^{2}$

2. Hasil Kelurahan Lowokwaru $=\sum \mathrm{ODV}=3332579,204$ $\mathrm{kbit} / \mathrm{hour} / \mathrm{km}^{2}=900.08 \mathrm{kbps} / \mathrm{km}^{2}$

3. Hasil Kelurahan Sumbersari $=\sum \mathrm{ODV}=3201123,078$ $\mathrm{kbit} / \mathrm{hour} / \mathrm{km}^{2}=864,58 \mathrm{kbps} / \mathrm{km}^{2}$.

\section{E. Kapasitas Sistem}

Perhitungan dalam menentukan kapasitas pada sistem seluler menggunakan rumus sebagai berikut [16]:

Strategi penambahan kapasitas sel $=\alpha \times \mathrm{y} \times \mathrm{B}$.

Keterangan:

$$
\begin{aligned}
& =4 / 5 \times 6 \times 100 \\
& =480 \mathrm{kbps} / \mathrm{sel}
\end{aligned}
$$

$\alpha \quad=$ Rasio download to upload ( 4/5 )

$\mathrm{y}=$ Efisiensi spectral rata-rata $5 \mathrm{G}$ pada jarak pendek (6 bps / Hz)

$\mathrm{BW}=$ Bandwidth $=100 \mathrm{MHz}$

\section{F. Perhitungan Jumlah Site}

TABEL VI

HASIL PERHITUNGAN JUMLAH SIZE DARI 3 KELURAHAN

\begin{tabular}{|l|l|l|l|}
\hline $\begin{array}{c}\text { Nama } \\
\text { Kelurahan }\end{array}$ & \multicolumn{1}{|c|}{$\begin{array}{c}\text { L } \\
\text { (Luas Cell } \\
\text { Coverage) }\end{array}$} & Esel & \multicolumn{1}{|c|}{$\begin{array}{c}\text { Radius } \\
\text { cell }\end{array}$} \\
\hline Dinoyo & $0,46828354 \mathrm{~km}^{2} / \mathrm{sel}$ & $\begin{array}{l}2,498 \approx 3 \\
\text { sel }\end{array}$ & $\begin{array}{l}0,4243 \\
\mathrm{~km}\end{array}$ \\
\hline Lowokwaru & $0,53328593 \mathrm{~km}^{2} / \mathrm{sel}$ & $\begin{array}{l}2,306 \approx 3 \\
\text { sel }\end{array}$ & $\begin{array}{l}0,4528 \\
\mathrm{~km}\end{array}$ \\
\hline Sumbersari & $0,55518286 \mathrm{~km}^{2} / \mathrm{sel}$ & $\begin{array}{l}2,305 \approx 3 \\
\text { sel }\end{array}$ & $\begin{array}{l}0,4620 \\
\mathrm{~km}\end{array}$ \\
\hline
\end{tabular}

Perhitungan kebutuhan jumlah site untuk mengetahui banyak base station/site yang dibutuhkan pada suatu daerah berdasarkan trafik penduduk dan jumlah site dapat dihitung berdasarkan jumlah kapasitas sistem. Berdasarkan perhitungan total ODV dan kapasitas sistem maka perhitungan jumlah site menggunakan rumus sebagai berikut [23]. Luas cell coverage (L), Jumlah cell dan Radius cell.

G. Analisa Pemetaan dan Penempatan Menara 5G

Gambar 7 adalah hasil simulasi Voronoi pada Map Info, dimana terdapat 11 site terpilih berdasarkan klasifikasi morfologi yang terletak pada 3 Kelurahan, yaitu Kelurahan Dinoyo, Kelurahan Lowokwaru dan Kelurahan Sumbersari dan berdasarkan klasifikasi POI terdapat 6 site potensi $5 \mathrm{G}$ dengan tanda lingkaran merah.

\section{Legenda dalam Gambar Voronoi adalah :}

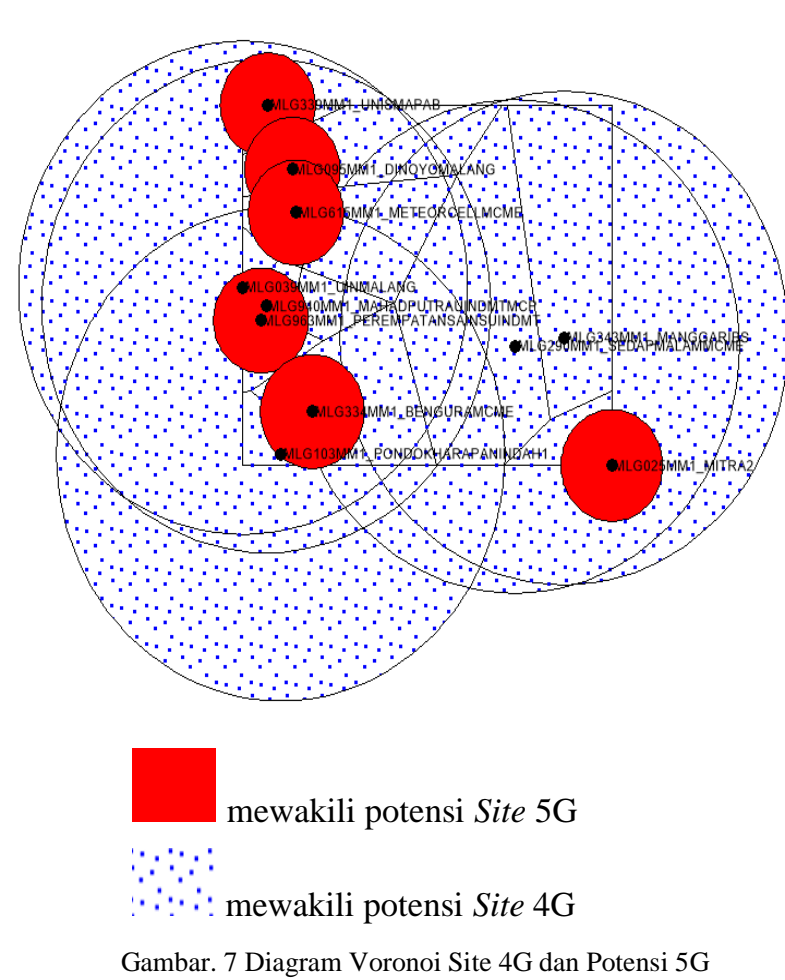

\section{KESIMPULAN}

Berdasarkan simulasi dan pengujian maka diperoleh hasil sebagai berikut:

Dari perhitungan trafik site $5 \mathrm{G}$ menggunakan formula over data volume (ODV), frekuensi $28 \mathrm{GHz}$, Bandwidth $100 \mathrm{MHz}$, jarak jangkauan (radius) antara 200m sampai $2 \mathrm{~km}$, micro cell (urban) atau daerah perkotaan, trafik dihitung pada jam sibuk dengan tinggi antena antara $4 \mathrm{~m}$ sampai 25 m. Jumlah ODV kelurahan Lowokwaru sebesar $900.08 \mathrm{Kbps} / \mathrm{km}^{2}$ terdapat 1 site yang potensi site $5 \mathrm{G}$, ODV kelurahan Dinoyo sebesar 1025,02 kbps $/ \mathrm{km}^{2}$ terdapat 4 site yang potensi site 5G, ODV kelurahan 
Sumbersari sebesar $864,58 \mathrm{kbps} / \mathrm{km}^{2}$ terdapat 1 site yang potensi site $5 \mathrm{G}$.

Pemetaan coverage 4G jarak jangkauan sampai $2 \mathrm{~km}$ lebih sedangkan coverage teknologi $5 \mathrm{G}$ jarak jangkauan antara $200 \mathrm{~m}$ sampai $2 \mathrm{~km}$ untuk micro cell (morfologi urban atau daerah perkotaan. Hasil pemetaan site $4 \mathrm{G}$ dan site 5G terdapat perbedaan radius (jarak jangkauan), sehingga pada saat di plot di diagram Voronoi radius 5G lebih pendek daripada radius $4 \mathrm{G}$, dan bisa terjadi over lapping antara 4G dan 5G.

Potensi kebutuhan site $5 \mathrm{G}$ di wilayah kecamatan Lowokwaru Malang sangat dibutuhkan karena kenaikan jumlah penduduk, dengan kenaikan jumlah penduduk juga naik jumlah pelanggan (user) pengguna smartphone. Melalui proses perhitungan kenaikan jumlah penduduk selama 5 tahun yang akan datang, klarifikasi morfologi, klarifikasi POI, kapasitas trafik, kapasitas atau kanal sistem, perhitungan jumlah site, luas cell coverage, jumlah sel, radius, dan diagram voronoi maka diperoleh potensi kebutuhan site $5 \mathrm{G}$ sebanyak 6 site.

Pemodelan site heterogen network $5 \mathrm{G}$ berdasarkan analisis kebutuhan site $5 \mathrm{G}$ di wilayah kecamatan Lowokwaru, pemodelan menggunakan diagram Voronoi Map Info pada suatu peta. Perencanaan dan pemetaan pada suatu peta coverage area memerlukan data Menara existing, menghitung coverage atau luas satu sel. Pemetaan berarti menetukan jarak terjauh (jari-jari sel) antara lokasi site dengan terminal pelanggan. Pemodelan dibandingkan dengan generasi sebelumnya yaitu $4 \mathrm{G}$ dan $5 \mathrm{G}$.

\section{UCAPAN TERIMA KASIH}

Peneliti mengucapkan terima kasih atas dukungan dana yang diberikan Politeknik Negeri Malang sehingga penelitian ini dapat terlaksana.

\section{REFERENSI}

[1] F. Awangga, "Pemetaan Riset Teknologi 5G," Buletin Pos dan Telekomunikasi, vol. 16, no. 1, pp. 27-40, 2018.

[2] T. Ervin and M. Achmad, "Perencanaan dan Penataan Menara Telekomunikasi Seluler Bersama di Kabupaten Sidoarjo Menggunakan Map Info," Jurnal Teknik ITS,, vol. 4, no. 1, pp. A36-A41, 2015.

[3] R. Mei, "Analisis Potensi Kebutuhan Enode-B di Kecamatan Lowokwaru Kota Malang,” Jurnal Jartel, vol. 9, no. 4, 2019.

[4] Aisah, "Realisasi Co-Location Tower/Site BTS di Malang Raya," Tekno, vol. 9, 2008.

[5] S. Ulil, "Kunci Teknologi 5G," Jurnal Ilmiah Teknologi Informasi Terapan Universitas Widyatama, vol. 4, no. 2, 2018.

[6] A. Rizal, "Analisis Pengaruh Tilting Antenna Terhadap Covrage Area Jaringan 4G LTE,” Jurnal JaRTel, vol. 9, no. 4, 2019.

[7] U. Hamzah, "Tantangan Implementasi 5G di Indonesia," Jurnal Teknologi Informasi, vol. 4, no. 2, 2019.

[8] "Point of Interest [POI] http:/gisindonesia.blogspot.com/2014/03/poi-points-of-interest.html (akses 28 Agustus 2021)".

[9] H. Choong, H. Sung, C. Kwang and G. Sung, , "Mobil Small Cell for FuRTher Enhanced 5G Heterogeneous Network," ETRI Journal, vol. 37, no. 5, 2015.

[10] K. Uke, "Small Cells sebagai Kunci Penentu Teknologi 5G," Fakultas Teknik Elektro, 2019

[11] "Badan Pusat Statistik Kota Malang https://malangkota.bps.go.id/ (akses 1 Maret 2021)".
[12] A. Sofyan and V. Rahayu., "Perencanaan Cell Plan di Kecamatan Bukit Raya Kota Pekanbaru Menggunakan Software MapInfo," FTEKNIK, vol. 4, no. 1, 2017

[13] "Methodhology for the Calculation of IMT-2000 Terrestrial Spectrum Requirements" Recommendation ITU-R M.1390".

[14] R. Michael, I. Jefrey and D. Esli, "Analisis Ketersediaan dan Kebutuhan Fasilitas Sosial di Kota Kotamobagu," Jurnal Spatial, vol. 6 , no. $2,2019$.

[15] "Kementrian Komunikasi dan Informatika, "Survey Penggunaan TIK," 2017.

[16] J. Edward, F. Zoraida, V. Sietse and S. Rudolf, "Assessing the capacity, coverage and cost of $5 \mathrm{G}$ infrastructure strategies: Analysis of the Netherlands," University of Oxford, 2019.

[17] S. Andika and F. Febrizal, "Perencanaan Jaringan Long Term Evolution (LTE) Menggunakan Parameter Existing di Universitas Riau," Jurnal FTEKNIK, vol. 4, no. 1, 2017.

[18] D. Y. Haq, “Optimalisasi dan Simulasi Jaringan 4G LTE di Area Universitas Muhammadiyah YogyakaRTa,” p. 2017, 2017.

[19] S. Slamet, "Analisis Penentuan Wilayah Fasilitas Kesehatan (Faskes) Rujukan Berjenjang Berbasis GIS Sebagai Dasar Distribusi Pelayanan Kesehatan Dengan Pendekatan Weighted Voronoi Diagram," Fakultas Teknik, Universitas Muria Kudus, 2019.

[20] PT Elex Media Komputindo. 2015. Sistem Informasi Geografis dengan Map Info. JakaRTa: PT Elex Media Komputindo.

[21] X. Feng and A. Murray, "Allocation using a heterogeneous space Voronoi diagram," Journal of Geographical Systems, 2018

[22] A. Bengawan, "Analisa Path Loss Radio Jaringan 5G Frekuens High Band $26 \mathrm{GHz}$ dengan Model 3GPP ETSI,” Jurnal Elektroda, vol. 5 , no. $1,2020$.

[23] "Peta Administrasi Kecamatan Lowokwaru https://www.wikiwand.com/id/Daftar_kecamatan_dan_kelurahan_ di Kota Malang (akses 28 Agustus 2021)". 